\title{
Time Travel: Australian Tourists and Britain's Past
}

\author{
Richard White, University of Sydney
}

Tourism is often under-rated as a causal factor in the sweep of history. In postcolonial histories of developing nations inbound tourism is acknowledged as a key dynamicanother form of imperialism - and the Grand Tour is recognised as transforming English culture in the eighteenth century. But in other histories, despite the growing body of work by historians of tourism, neither inbound nor outbound tourism is normally considered as a force for change, perhaps because many historians share the disdain for the figure of the tourist that is so embedded in the history of travel (Buzard 1993). Yet in Australia, for example, the impact of outward bound tourism has arguably been one of the decisive factors in transformations in Australian culture through the twentieth century. The omission might be understandable in introspective nationalist histories but even with the transnational turn, tourism is often relegated to the margins.

Australians are among the world's most travelled peoples, despite the fact that historically it has been harder to travel the world from Australia than just about anywhere else, particularly when Europe was the primary destination as it was until the 1970s. There has been an enormous investment in overseas travel—an economic, cultural and emotional investment - and the figure of the Australian Abroad has long had a resonance in Australian culture. The impact of overseas travel appears in all sorts of unexpected places. It plays a large part in shaping and maintaining Bourdieu-esque notions of distinction, taste and sophistication: the capacity and desire to travel have long depended on class identities and the travel experience is still a marker of social status. National identity can be forged in stories about innocent Australians abroad 
(White, R. 2001; Sobocinska 2011). Transformations in the food we eat have come less from migration than from international tourism, which has introduced different food experiences and associated them with sophisticated taste (Symons 1982). And in foreign policy, it is arguable that the humble tourist preceded the professional diplomat in reviewing notions of Australia's Britishness (Trinca 2009; 2010) and engaging with Asia (Sobocinska 2010a; 2010b). Together such examples show both that travel complicates any simple teleologies from Britishness to Australianness and that Australians abroad - travellers, tourists, even businessmen in their face to face meetings - are the makers of history.

With the conviction that the experiences of ordinary travellers can tell us much about cultural assumptions, this article examines the relationship Australians had to Britain, looking through the prism of their understanding of the past. It argues that the Australian tourist's response to Britain's past was often deeply emotional, but that it was more the product of personal nostalgia and a broader sense of a generic past than an expression of empire loyalty. This response seemed to cross age, gender and political divisions and persisted over time. The focus is on the ordinary run of Australians, rather than expatriates or intellectuals, visiting Europe between about 1900 and the 1970s (Pesman et al. 1996b). ${ }^{1}$ They produced a range of travel accounts, from published works to diaries and letters. There are differences between published travel writing and tourist diaries, but they are fewer than might be expected. Australia's most popular travel writers tended to reject the tourist-traveller distinctions that usually infect published travel accounts (Holland \& Huggan 1998), claiming to be more 'tourist' than 'traveller' (White, R. 1997, 2009, 2012).

At the beginning of the twentieth century, Australia's best-known travel writer was Nathan Spielvogel (1874-1956), a country schoolteacher who spent his savings of $£ 120$ on a trip to Europe. His Gumsucker on the Tramp of 1905 had sales comparable per capita to Mark Twain's Innocents Abroad (Pesman et al. 1996a: 69). Spielvogel represented what might be called a Bulletin school of travel writing, sharing the radicalism and strident nationalism of the influential weekly, which took him up. Other significant figures were J. H. M. Abbott (1874-1953), another Bulletin writer, who

\footnotetext{
${ }^{1}$ Expatriate intellectuals have already been well-served by, among others, Stephen Alomes (1999) and Ian Britain (1997), as have been earlier tourists (Hassam 2000).
} 
published An Outlander in England: Being Some Impressions of An Australian Abroad in London in 1905, and Randolph Bedford (1868-1941), whose neatly titled Explorations in Civilization appeared as Bulletin articles in 1901-1904 and in book form in 1914. These writers played up their Australianness, asserting their difference from Britons with an insistent though not uncritical nationalism. They were middleclass liberals, staunchly democratic and nativist, supporters of so-called 'colonial socialism.' They saw the novel social arrangements of the new world as superior to those of the old, which they identified with rigid class hierarchies, poverty and stultifying tradition. Britain was history: when Spielvogel's ship was in the Bay of Biscay, he felt the wind 'blowing me a welcome from England and the past' (Spielvogel 1907: 5). They admired the enormity of the past they found in Britain, but also saw it as a burden.

And so when it came to an understanding of the relevance of the past, they could play on the relationship between the old and new world in ways that challenged the assumption that old Europe was necessarily superior. Abbott inverted it altogether. He began his book with the conceit that to an Australian, Australia is the old world and England the new. Sailing out of Sydney he felt his own country was

\footnotetext{
the 'old land.' And at sixteen knots an hour you were making your way to another that was older than your own by thousands of years, and yet to yourself was new and unexplored and pregnant with possibilities of undiscovered and inexperienced things ... the country where any man is born is the Old Land to him, whether it have a history of two thousand or of fifty years. If its only ruins are broken-down fences, or the rotting corner posts of stockyards erected a generation ago, they must be to him the milestones of such civilisation as he knows of. (Abbott 1905: 9-11)
}

The importance of ruins will be a continuing thread, as we will see. For now we should note that this Bulletin strand of assertively Australian travel sat alongside the many other Australian travellers who thought of themselves as British and shared the assumption of Australia's inferiority. However the gulf between the radical nationalist and the conventional colonial should not be over-stated. Most travellers-nationalist or imperialist - were ready to balance admiration with criticism, reflecting both positively and negatively back on Australia. Australians of all political stripes criticised English food, for example (White \& Oldmeadow 2009), while most were in awe of the history. ${ }^{2}$ In this reverence for Britain's past, we might see something of what one group of historians has categorised as a shared 'British race patriotism' (Meaney 2001; Ward

\footnotetext{
${ }^{2}$ This is in complete contrast to Britons in Australia, who generally ignored the past (White, R. 2013).
} 
2001: 2; Curran 2004: 18). If we probe this more deeply however, there emerges, among these tourists and travellers, a more complex picture in which emotion and social memory are entwined and in which overt patriotisms have very little place.

\section{Connecting to the past}

For much of Australia's history-well into the second half of the twentieth century I would argue and with resonances that linger in the tourism industry even todayAustralians have crudely but conveniently categorised the world into three. The world's peoples were British, foreign or native (White, R. 1987a). The British world, including the United States and the British dominions, was English-speaking, sensible and civilised. Continental Europe was civilised, containing world powers that competed with the might of Britain, with cultures that even outshone Britain in music and art, but the people were unpredictable, their politics unreliable, their religion impossible. And then there was the rest of the world, the object of Europe's imperial reach, uncivilised or semi-civilised peoples who could only benefit from the gift of British civilisation or modernisation.

This tripartite division of the world corresponded roughly to three ways of understanding the past. The British past was ennobling, a living past that was the heritage of English-speaking people around the world, a pattern of steady progress in the Whig tradition. The European past was romantic, bloody, inexplicable: think of all the complex associations of that term 'continental' — sophistication, cosmopolitanism, a degree of sexual licence (Barr 2009). It lent itself more to a regency romance bodice ripper, a perspective that perhaps dates to the Grand Tour for men and to Byron for women. The 'native' past was traditional and unchanging, with such a weight of history that inertia was the normal condition requiring the galvanisation of a European presence to be jolted into movement. ${ }^{3}$ Obviously these are very crude categories and this perspective on the world is not limited to Australia, but the pasts that Australians explored beyond Australia do seem, at least for much of Australia's white history, to have fitted this pattern. ${ }^{4}$

\footnotetext{
${ }^{3}$ These have interesting parallels, though are not entirely consistent, with Hayden White's 'emplotments' of Romance, Comedy, Tragedy and Satire (1973). Nietzsche's trio of monumental, antiquarian and critical histories could be manifested in each historical setting (1980).

${ }^{4}$ And it is still visible: see, for example, the Fairfax press Japan travel supplement, 'Japan: Land of Beauty, Mystery and Living Tradition,' Sydney Morning Herald (27 January 2011: 4, 6, 12, 14-15, 16, 20).
} 
Needless to say, Australians readily identified with the British past, as something they could connect themselves to. It was something they imagined sharing or even owning. Jessie Sisson, in a travel guide written for the Bank of New South Wales in time for the Coronation of 1953, was the most bluntly proprietorial: 'The history of the country ... is magnificent and lends a romance and enchantment that can be felt. And above all, it is ours. It is our heritage. From some corner of this little land, we, or our forebears, came. Its history and its beauty are ours and in its present and in its future we are concerned' (1953: 1). This sense of belonging and connectedness to Britain's past often had a personal dimension, reflecting a direct family tie still part of family memory. For one enthusiastic family historian researching 'my line of people' in Penzance in 1960: 'It seems a little strange and unreal for me to be walking in the roads and streets where my Maddern forebears walked 400 years ago, and almost certainly for hundreds of years earlier than that.' He visited the parish church,

which we had not visited for 104 years. That is a Celticism, if you like. I'm afraid I did not listen very carefully to the sermon, but rather dreamed about my people baptized, married and buried at the church for centuries. I suppose my grandfather, old Solomon Maddern, went to church here on his last Sunday in ... Cornwall, 104 years ago, and we are the first members of his family to return here.' (1960: 22-23, 26)

Elite travellers with family vaults to visit naturally felt a particularly personal connection. In Worcester, Lady Street thought the Street monument 'very fine and quite worthy of the family' (1929: 4 September). Washington Soul, of the pharmaceutical dynasty, visited 'Abney Park Cemetry [sic] — I found the old grave at once — it is an immense place - the stone is not in very good order, gave Dunkley instructions to get it right and add Father's and Mother's names' (1899: 6 June). Others were happy enough simply 'to see the graves of our ancestors' and take 'snap-shots of a couple of headstones' (Millear 1902: 135).

More often the connections to the past were less direct and indeed it is surprising how little active family history there was until late in the twentieth century. Nevertheless many insisted that what they saw had to do with 'memory,' even though most had never visited Britain before. In 1913 the New Zealand politician J. R. Sinclair commented that 'The colonist instinctively seeks things that have age, around which memories cling' (Sinclair 1913: 10). London promised 'the marvellous fascination of this old place of so many memories' (Sommerlad 1939: 20 July). In Edinburgh 'Memories of Burns and Scott, Knox and a dozen other well known names, meet one at every corner' (James, 
Florence 1928: 12 August). The nature of this memory needs unpicking. In one sense it is the prosthetic social memory derived from the Anglo-centric culture they grew up with, especially through reading and lessons learnt at school and stories told at home. But its real nostalgic power came from the way the nebulous social memory of British History could be confused and entwined with quite specific personal memories of schooldays and childhood reading. Allan Brown, an Australian soldier training at Wareham in 1916, was taken with nearby Corfe Castle, 'a very ancient castle which we read about in the history books at school ... the castle the Roman soldiers could never take ... I visited this place a few times, as I fell in love with the old fashioned little village' (Brown 1916-17: 78-79; White, R. 1987b). There is a sense of a soldier's homesickness here, that takes us back to the original meaning of nostalgia: the little village represents less a social memory of the old country than a personal memory of schoolbooks buried somewhere in an Australian childhood.

Thus tourists linked their experience of Britain's past with their own memories of younger days and youthful yearnings back in Australia. Allison Howorth was thrilled by 'all the historical memories of our school-days' (1937: 52). In 1928, at Lanrick mead, the 'muster-place' of The Lady of the Lake, Mabel Dowding exclaimed 'How that old school book lived again today!' (1928: 28 May) and on another trip, 28 years later, found herself again driving 'thro' history book country' (1956: 16 July). For Stuart Gore, Plymouth Hoe was 'a magical name to Australians, nurtured in school-days on the sea-faring tradition of their Mother country' (1958: 79). In the Tower of London in 1909, Lindon Brown 'could hardly realise that I was walking through places associated with the earliest times of England, and that to me previously had only existed in "Little Arthur's History" or "Magnall's Questions"' (1910: 53). Even Julien Nixon, who had not paid much attention to his schoolbooks, had some idea of what was in them: 'Scotland and England are chock full of old Castles - and a number of them must be refer'd to in our School Histories' (1928: 29 February). Being there brought to life the English history that dominated the Australian curriculum until the 1960s, but more importantly the emotional attachment to Britain's past acquired a significant edge because it could conjure up a nostalgia for a personal past.

Australian tourists generally marvelled at how the past known through books came alive in Britain: one of the conventions of Australian travel abroad was how it was like 
entering a schoolbook or a play (White, R. 1986). And there was just so much of it: 'History hits you everywhere' (Garnsey 1930: 7 August); 'something fascinatingly old is always turning up ... Every common thing is alive with history' (Sommerlad 1939: 20 July); London was 'throbbing with historical life' (Dowding 1928: 27 June). In Westminster Abbey in 1953, Esther Corsellis could even smell it: 'It smells of age ... a smell I have never known at home' (1953-54: 4 December 1953). On a second visit, in 1975, when her host apologised for the prospect of a boring drive, this enthusiastic member of the National Trust protested: 'but of course it was not so for me, with at least 3 Wars of the Roses battlefields, 3 mouldering castles, \& a few stately homes' along the route (1975: 5 September). From London, Sheila Glading wrote that 'All the buildings look as though they are reeking with age and interest, which of course they are.' She was pleased with that phrase: in her next letter it was Windsor that 'looked as if it was reeking with age and interest' (Glading 1946: 11 August, 17 September).

With connections to famous historical and literary names scattered along the standard tourist routes, travel provided fertile ground for celebrity-spotting, long before it was noticed by cultural studies. Literary tourism was well-established in the nineteenth century (Watson 2006), and historical figures also attracted the tourist's attention. In 1901 they were spotted in Westminster Abbey, 'the last resting place of many celebrities' (Lloyd 1901: 27), and in 1922 in St Paul's: 'What an accumulation of decayed genius rests within these ponderous walls' (Moss 1922: 51). Elliott Napier was impressed by the 'veritable army of famous names' associated with the Temple courts (1933: 82). Leonard Kendall was thrilled that 'Bath has probably more associations with celebrities of the past than any place in the country, excepting London' and that Oxford's colleges, all 'steeped in history and tradition,' had 'turned out hundreds of famous men' $(1951: 151,99)$. It was less a matter of rubbing shoulders with the famous as rubbing shoulders with the past.

What crucially distinguished British from 'foreign' history for Australians was the way in which, at least until well into the late twentieth century, it was part of a flow of history that they understood as relevant to them, a Whig dynamic of progress connecting the past to the present. Moreover it was a history into which they could readily insert themselves. Many scholars have drawn distinctions between a remote bookish history and the lived pastness of everyday life (Nora 1989; Samuel 1994; 
Lowenthal 1985; Atkinson 2003). The history presented to tourists is often seen as packaged, commodified spectacle, dissociated from real life. But what is striking is how actively many Australians identified with a flow of history that nevertheless was so distant from their ordinary lives. Judy Brett has brilliantly analysed this sense of connection to a living British past in the worldview of Robert Menzies (Brett 1992: 135-55). Certainly staunch monarchists found in the lineage of British monarchs a direct, relevant line from the past to the present. As Edith Lahey put it, 'speechless' in the cathedral at Canterbury, 'the "Mother City" of the British Empire,' on the eve of war: 'Think of the many Monarchs who have gone through, the penitent Henry II walking through the Crypt in his linen robe, bare footed and weeping, and so and on to our own King's time' (1941: 51). At Chepstow, Washington Soul found 'a perfect old ruin—only good joining the past with the present' (1899: 25 May). In 1929 Sir Philip Street, Chief Justice of NSW, dined in Middle Temple's 'old historical hall in which Shakespeare produced his Twelfth Night before Queen Elizabeth' and found the opportunity for a homily to his son Ernest:

the more that I see of the continuity of the history of the people of England and of the mingling of the past with the present the more impressed I become with the stimulus that such things should be to their educated young men and women of England and with the inspiration that they should draw from them to live worthily and to become useful members of the community. (1929: 16 June)

But this sense of history flowing through the present certainly was not the sole preserve of the British-to-the-bootstraps brigade. In 1905 for example, J. H. M. Abbott found it visiting Oxford. There he returned to his trope of Australian ruins, against which Oxford was 'unreadable':

\footnotetext{
to us who find an old Georgian verandahless house a quaint survival of bygone days; who ride past the grey posts of broken-down stockyards, idly wondering what kind of prehistoric people branded cattle in them; who have marked Captain Cook's landing-place at Botany Bay as a monument to the dawn of our civilisation, - Oxford is a little unreal ... It is so old, so quiet, so beautiful. The grey walls of college and hall, chapel and cloister ... and worn stone pavement, are of to-day and of yesterday, and of many yesterdays ... Somehow, in some way you can only vaguely realise, Past and Present and Future are united here. (Abbott 1905: 78-83)
}

In 1958, the youngish and mildly mischievous journalist, Stuart Gore, was uncharacteristically sentimental when contemplating Plymouth Hoe. After lampooning Americans' devotion to the Mayflower and family trees, he nevertheless felt he owned Plymouth's past:

We, whose ties with the Old Country are more recent, strong, and binding have no special interest in thus accurately pinpointing our ancestry. Perhaps wisely. 
But we can and do, have the best of both worlds on Plymouth Hoe. Faith in the future of the new country which is ours mingles equally with pride in the past exploits of the Old Country — which is also ours. (1958: 80)

Journalist Florence James found an instinctive fit in 1927: 'This is so curious to be in these old historical places at last, and yet so natural' (1927: 4 November).

Even when the history was as barbarous as that found in the dungeons of Carlisle Castle, the connections could still be made, placing the tourist in a stream of history flowing from barbarity to civilisation: 'There certainly were brutes living in past ages and one hates to think they were our ancestors' (James, A. H. C. 1930: 7 August). In the Tower of London in 1901, one was grateful that 'our lot was not cast in those days of darkness and barbarity' but lived 'in an age when our land has received the blessings of enlightenment' (Lloyd 1901: 28). Just over a decade after the Somme, young Julien Nixon wrote to his mother: 'Did these early people of this Isle ever dream that we moderns would be idling on their crumbling Castle -, living in a very different and more civilised world?' (1927: 18 December).

Many went further than simply sharing a common British connection to the past: they claimed that Australians appreciated it more intensely than the British themselves. Frank Clune, that pugnacious Irish-Australian nationalist, on his first trip to England at the age of 53, was shocked at English indifference to the past: 'Londoners, I'm told, take very little interest in their abundant memorials of past days and bloody deeds, but it's enchanting to a visitor from the Antipodes' (Clune 1949: 15). In 1900, Washington H. Soul saw Cleopatra's 'Needle' and complained that 'the smoke of dirty London has done it more harm than centuries in Egypt' (1899: 16 May). Edith Lahey was saddened: 'How the people of England can bear to see the beautiful old buildings torn down and the garish new ones put up in their places I do not know' (1941: 43). And for James Penn Boucaut, judge and ex-premier, who travelled in 1892, it was 'a daily grief to me on visiting these dear old churches to see what indifference there has been in the past to our glorious history and interesting relics' (1906: 86).

Being 'ours' gave additional edge to the regular complaint of having to pay for it: 'What I hate most about these venerable places is being charged to go here and there' (Brown, L. 1910: 50); 'it is mean' grumbled wealthy Washington Soul (1899: 4 October). More commonly though, in the cost-benefit accounts of the tourist, Britain's past was 
considered 'well worth it' (Corsellis 1953: 4 December; Campbell 1932: 10 December; Lahey 1941: 163).

These travellers were even more outraged when Australia was not given its rightful place in this shared saga of British history. They were always on the lookout for Australian connections and Captain Cook, as the British 'discoverer' of Australia, was the touchstone that confirmed their sense of belonging. Sites connected to Cook were being marked out in the mid-nineteenth century, though the 'Captain James Cook Heritage Trail' was not opened until 1978 (Walton 2009: 222-24). Jack Moss found himself in Mile End Road in 1922: 'Somewhere here Captain Cook lived, so this street is of interest to all good Aussies' (1922: 50). The failure to acknowledge Australians' claim on Captain Cook was a particular concern. In Cambridge in 1930, A. H. Garnsey 'discovered' the graves of Cook's family and a plaque on the chancel wall: 'Only he was simply described as a great Navigator who was killed at Owyhee, and his discovery of Australia is not even mentioned' (1930: 30 October; cf 21 August). In 1953, Esther Corsellis was put out by the fuss made of the fact the Mayflower sailed from Plymouth: 'So, I think did Captain Cook, although there is no tablet to him. I took it up with the Information Bureau, but I was not sure enough of my facts- he may have sailed from Southampton' (1953: 27 April). ${ }^{5}$ At the naval museum in Greenwich, her frustration boiled over: 'Was disgusted with the Captain Cook section. The discovery of Australia was passed off as "other important discoveries in the South Seas."' (1953-1954: 4 April 1954). Such omissions were taken as personal affronts. So Australian travellers not only felt personally connected to the British past, but claimed their own rights to it, rights that were distinct from and often superior to those of Britons.

\section{The necessity of ruins}

Britain's past — and the passing of time in general — was most tangibly expressed in the ruin. Humankind has long enjoyed the pleasure of ruins, as Rose Macaulay put it (1953), and tourists have long sought them out. Romanticism added considerably to the frisson. Ian Ousby noted that 'Ruins were admired as witnesses to the triumph of time and nature over man's handiwork' (despite Henry VIII's hand in their creation). The 'pleasant, pensive melancholy they provoked' was perhaps most fully expressed in Gray’s 'Elegy Written in a Country Churchyard' (Ousby 1990: 126). The churchyard

\footnotetext{
${ }^{5}$ She should have had more faith in herself: he sailed from Plymouth.
} 
itself, at Stoke Poges, was a popular stop on the literary tourist trail (Sinclair 1913: 1112; Sanders 1928-1929: 42; Twigg 1968: 17 July; Watson 2006: 39ff). ${ }^{6}$ To these travellers from the new world, ruins had further meaning, and those in England, where the cult of the ruin was most thoroughly celebrated, meant more than any others. The contrast between the decay of the old world and the lack of ruins in the new reinforced the temporal connection between Britain and Australia and gave it an emotional edge.

But they did not come to gloat about Britain's decline. The idea of the new world gazing on the ruins of the old became a renowned cliché after 1840, when Lord Macaulay $^{7}$ placed his solitary New Zealander 'on a broken arch of London Bridge to sketch the ruins of St. Paul's' (Macaulay 1840; Skilton 2004). To Victorian Britain the image was symptomatic of deep anxieties about the decline and fall of empires. In the colonies, however, Britain's might and glory was simply an ever-present, immutable fact. Few antipodean tourists saw ruins through the nationalist prism of their own future eminence. Instead they came in awe of Britain's past: Britain's past glories were one with its present. Ruins were necessary as a sure sign of the depth of a civilisation. Hence Abbott's affection for Australian ruins, despite their paucity (1905: 10-11, 78). Hence the popular enthusiasm for the ivy-clad convict ruins of Port Arthur (Young 1996: 3637). Hence the facetious proposal, by the bohemian nationalists of the $1890 \mathrm{~s}$, that they 'establish a society for the erection of ancient ruins in Australia' (Taylor 1918: 10-12; White, R. 1981: 95-96). The inadequacy of ruins in Australia exposed the thinness of its culture.

So most Australians were enthusiastic about Britain's ruins. Ilsa Blomfield passed Netley Abbey not long after arriving: 'it was the first ruin I had ever seen, to one who has lived in a new country without generations of historical landmarks the ruined Abbey brought up pictures of many things I have read of England as a child' (1909: 92-93). Flora Blakie, on a Cook's Tour in Scotland in 1903, visited Melrose 'and went over the abbey which is so well known to all lovers of ruins ... There is something very sad in these dear old ruins how sad that they should be ruins' (25 July). At Glastonbury, Allison Howorth's experience bordered on the mystical: 'I cannot tell you how these

\footnotetext{
${ }^{6}$ As an aside, when I first typed this line a serendipitous typo transposed the R and A in Gray and illustrated how Australian ruins could never match the gravitas of British ones: 'Gary's Elegy Written in a Country Churchyard' does not have quite the same ring to it.

${ }^{7}$ Rose Macaulay's grandfather's cousin.
} 
ruins affect us - they must be seen. A strange peacefulness pervades the whole place.' In the kitchen,

where the monks or abbots, or whatever they were called, used to cook their food. I closed my eyes for a moment, and at once I saw them, in their long cloaks and cowls, standing round an old brazier in which red charcoal was burning. They were stirring something in a big iron pot, which looked like porridge ... I felt better for having seen them, and was at peace with the world. (1937: 29-30)

Even Washington Soul's entrepreneurial utilitarianism was confused by Tintern Abbey:

with all its uselessness it would be a pity to take it all down - it is a fine old place of the long past - immensely strong — the same old wooden door admitted us that admitted those of hundreds of years ago-This old ruin ... is also to be sold it is said - should it be taken down-Tintern is done for-fairly an old ruin but the sole support of a small town - for sight seers, but Pompeii is the same ... where the old floors have been, we could fancy the monks of old - with the nonsence (sic) of the Roman Catholic Church enactments ... a splendid show—now a show ruin. (1899: 25 May)

They became connoisseurs of ruins. Conway Castle had 'fine ruins - the finest, I think, that I have seen' (Sinclair 1913: 6) and Chepstow was 'a perfect old ruin' (Washington Soul 1899: 25 May). They measured them up against each other, commented on the aesthetics of ivy-covered walls, the relative merits of grass or gravel floors, the effect of their setting in the landscape: 'the fine ruins of the well-placed castle' at Rochester (Sinclair 1913: 7). Gertrude Soul also admired Chepstow and contributed to its ruination:

It is a grand ruin now ... destroyed by order of Cromwell. In some places the walls are about 2 yards in thickness, so it must have taken some time to destroy it as we see it now, but of course time has also spent its ravages there ... I broke a little piece of the wall off with the end of my parasol, but it was hard. (1899: 25 May)

In contemplating the ravages of time, a few admitted to assisting the process by souveniring the past. Gertrude was incorrigible. Not only was there this bit of Chepstow Castle: at Camp Hill, with its associations with the Wars of the Roses, 'I picked up a few stones from there, and then we went down again' (1899: 31 May). To own a bit of Shakespeare, her husband at least paid for 'a slip of paper with infusion from the grave.' And 70 years later: 'at a Church at Stoke-Poges where Thomas Gray wrote his Elegy under a yew tree which is about 900 years old. Des snitched a piece of the tree which is pressed herein' (Twigg 1968: 17 July).

There were Australians less enamoured of Britain's history, probably far more than admitted it in writing. There were moments such as that at Jedburgh, when a tour group 
jacked up and 'bellowed we'd seen enough ruins' (Dowding 1928: 25 May). Boucaut admitted 'Museums and picture galleries make my head ache' (1906: 122). Washington Soul also had his limits. He had had a solid two months' sightseeing, noting 'fine' old places 12 times ('fine' being his favourite word, usually applied to intact oldness). At Newbury he cracked:

the place is an old one, some old ruins are to be seen, for my part I have seen enough of rubbishsome are pretty but they want to come down - and then they charge you to look at old stonesanyway there is a charm in age-Dickens said 'he had never seen a man who liked to boast of and retain an old hat or boots, but old ruins and crazed crockery fetched fancy prices.' (1899: 12 July)

Perhaps he felt the discovery of that quote from Dickens licensed his impertinence. At Tintern Stuart Campbell was even blunter:

after all one ruined abbey is very much like another to me. I can't honestly say I was a bit interested ... Arthur Tickle [his host] has the history of it all off pat and also the history of numerous other places round here. He poured out a lot of it on me but frankly I was bored. I wonder if I'm really as much of a unique Philistine as I seem or do other people adopt a pose over history (1933: 31 June).

Joan Boxall's letters home show her gradually becoming fed up with history. On an early excursion in 1952, Canterbury was 'very ancient and interesting.' But a year later she was yearning for 'the barely touched freshness of Alice Springs and the striveness [sic] of pioneers rather than this preoccupation with the Past'; a month later 'I don't want to stay here Forever its all too ruddy museumlike - fancy living in a museum'; and eventually:

\footnotetext{
All looks FORWARD in Aus - here its flaming Old Abbey - St Paul's statues and decorations being eaten away with smog \& not a square inch of virgin land anywhere - everywhere King Alfred sat or Ellen Terry slept—\& their ruddy stately homes (1952: 17 April; 1953: 28 June; 21 July; 11 November).
}

But such admissions were rare. The vast majority looked on Britain's past with wonder, 'overwhelmed by the riches of the centuries and the weight of time' as Esther Corsellis put it (1954: 16 January). Apart from deploring its brutality, few brought any social critique to their largely rose-tinted appreciation of history. Arthur Garnsey, from a family of socially-progressive clergymen, was unusual in seeing the past cheek by jowl with poverty: 'Everybody knows that Chester is old, historical and picturesque. I am sorry to have to add that is has some horrible slummy quarters, miserable tiny terrace houses abutting right on to the streets' (1930: 18 June). A great many other Australians condemned old world poverty when commenting on other aspects of British life 
(Roberts, A. 2008; White, R. 1986), but the past tended to be kept sacrosanct and safe from such unpleasantness. Allison Howorth's view was more complicated:

Then, of course, what makes an old country so interesting from the tourist's point of view, are its traditions and history - but surely much of it is a history no new country wants. Our little bit of convict history is sad and dreadful enough. Much as I enjoyed seeing the old castles, I was always conscious of the horrors that had taken place there. (Howorth 1937: 151)

Howarth, the happily gushing author of 'Cooee' England, was hardly a radical nationalist yet, exceptionally, she suggested the burden of the past might be too heavy.

\title{
A history of the emotions
}

How do we explain the depth of emotion that so many Australians brought to their encounters with such a rich past? They were certainly deeply moved. Elliott Napier, a digger-journalist who walked 'the Homeland's history-haunted ways' on leave during the Great War,

had all my life hoped to visit England, and, of all English towns, I had most wished to walk the streets of Stratford. And here it lay ... And at the sight I felt that swift, heart-stopping shiver which, as upon the hearing of majestic music, accompanies the rarest ecstasy that man may know-the perfect consummation of a deep and long-sustained desire! (1933: Dedication, 69)

Somewhat less articulate, Julien Nixon felt similarly fulfilled in the cottage of Dr Livingstone, a childhood hero: 'Little did I think I would one day glimpse this venerable spot ... Livingstone's room ... gives use to very strange feelings to ones fibre' (1928: 29 October). Not long after the Blitz, Leonard Kendall was stirred by Big Ben:

\begin{abstract}
that clock seems a citadel of strength in a chaotic universe. The wonderful sound of its deep mellow chimes, even relayed on the radio ... continues to thrill myriads who hear these tones. The very sight of it is inspiring. Everywhere it is the same in this enchanted land. Centuries of eventful history and tradition seem to be so much bound up in some of these things that the mere sight or sound of them has a strangely stirring effect. (1951:24)
\end{abstract}

Many diarists recorded that 'thrill' of history and, though they often descended into cliché, they seemed to be striving to suggest the depth of the emotion when encountering a past long identified with and previously only imagined-Napier's 'heartstopping shiver' (1933: 69). ${ }^{8}$ The changing of the guard was 'thrilling' (Pattinson 2007: 38); an original Dickens manuscript was 'rather thrilling' (Dowding 1928: 29 June); living in a castle was 'really very thrilling' (Pattinson 2007: 78). Exeter had a 'thrilling history’ (Kendall 1951: 85); Middle Temple ‘never fails to thrill me' (James, Florence

\footnotetext{
${ }^{8}$ Freud read the emotional intensity of such occasions as Oedipal (1936; White, R. 1986).
} 
1933: 22 March); York Minster 'was a thrill to see ... \& to learn its ancient history' (Sommerlad 1939: 10 July). For Arthur Garnsey, the site of the old Tolbooth in The Heart of Midlothian was 'thrilling' and then 'The next thriller was the Pass of Killiecrankie (get out your historybooks again)' (Garnsey 1930: 22 June, 29 June). The Scottish border 'thrilled us to the marrow ... with all the historical memories of our school-days' (Howorth 1937: 52) and at Bannockburn 'One couldn't help a thrill in passing thro' this old historical country' (Dowding 1928: 28 May). 'Hampton Court has quite an interesting and thrilling history and I shall later send you a very descriptive pamphlet on it' wrote Faye Pattinson on a working holiday in 1954 (2007: 47). The laconic Reveda Lawrence 'Went to see Dickens House in Doughty St. Thrilled' (Lawrence 1930: 29 June). This was not simply a corporeal sensation, as might be triggered by sublimity in nature - or a ride at Luna Park - though it did seem to include a physical component. Nor was it often bound up with expressions of loyalty to the empire or race patriotism. The emotions went deeper, partly the culmination of something long anticipated, partly nostalgia for the imaginative world of schooldays, but also a sense that it was through history, not through geography, through time not space, that they had reached another world.

Other favourite adjectives were gentler. The emotional connection was personalised and proprietorial, as we can see particularly in the use of the adjective 'dear,' so simple and so intimate in the 'dear old ruins' (Blakie 1903: 25 July). Ruins were not all: there were 'dear old churches' (Boucaut 1906: 86), 'dear old' villages (Lahey 1941: 43), other 'dear old places' (Boucaut 1906: 103) and of course 'dear old England' itself (Spielvogel 1907: 33), enough for 'Dear old England' at times to be used satirically (Hinder 1911-12). And what gave added intensity to the emotion was their frustration at their distance, the necessity of leaving the English as guardians of this past and the knowledge they were not very good at it. ${ }^{9}$ So Edith Lahey lamented:

The dear little old village now has a new suburb close by, a blaring, glaring place ... The little old place is being allowed to fall to pieces, no paint where a little would revive, no plaster where little repairs would keep the old world beauty. That place seemed to me just a little, gentle old place waiting and suffering patiently and quietly until 'Progress' — so called-smashes its way in and kills it. (1941: 43-44)

Alongside the 'dear old' past were 'quaint old' customs (Kendall 1951: 122; Menzies

\footnotetext{
${ }^{9}$ The same sentiment that led so many US philanthropists and some Australians to underwrite historical preservation: see Lahey (1941: 51).
} 
in Brett 1992: 139), 'quaint old' gateways (Kendall 1951: 124), 'quaint old' houses (Lahey 1941: 72), 'quaint old' inns (Lahey 1941: 55; Nixon 1928: 24 April) and 'quaint old' inn signs (Cohen 1938: 8 October; Spielvogel 1907: 29), 'quaint old' streets (Cohen 1938: 11 October; Lahey 1941: 55), ‘quaint old' alleys (James, Florence 1928: 12 August), 'quaint old' churches (Garnsey 1930: vol. 1, 49; Kendall 1951: 130), 'quaint old' rooms (Washington Soul 1899: 4 October) and 'quaint old half-timbered over-hanging houses’ (Kendall 1951: 86); Keswick was 'very very quaint' (Dowding 1928: 23 June) and Chichester was 'most quaint and winsome' (Garnsey 1930: 10 June). Old houses (Girl Guides 1937: 8 December; Roberts, H. G. 1937: 14 May), squares (Garnsey 1930: 21 August), cottages (James, A. H. C. 1930: 1 June; Glading 1948: 4 April), buildings (Lawrence 1930: 28 June), corners (Kendall 1951: 82), fireplaces (Lahey 1941: 56), farmers (Nixon 1929: 27 July), church fonts (Napier 1933: 10), towns (Nixon 1928: 26 September) and windows (Falkiner 1938: 13 July), along with Wells (McDonald 1944: 148), York (Sommerlad 1939: 10 July) and the Brighton Pavilion (Garnsey 1930: 3 June), could all be 'quaint.' So could the beefeaters (Falkiner 1938: 13 July).

The past was picturesque too. Chester (Donnell 1917: 1 March; Garnsey 1930: 18 June), Durham (Lahey 1941: 70), Exeter (Napier 1933: 26), the Menai Strait bridge (Cohen 1938: 19 October) and Anne Hatherway's cottage (Cohen 1938: 26 October), the ruins of Rosslyn Castle (Garnsey 1930: 22 June) and Castle Urquhart (Garnsey 1930: 2 July), Salisbury Cathedral (James, A.H.C. 1930: 1 June), Hexham market place (Lahey 1941: 72), Warwick Castle (Sanders 1928-29: 36) and Stonegate in York (Street, Sir P. 1929: 11 August) all scored that accolade. Craigmiller Castle was 'a wonderful old ruin, very picturesque, and covered with ivy' (Reid 1900: 17 July) and, again, the beefeaters were 'picturesque' (Richardson 1904: 12 August). While 'quaint' and 'picturesque' are standard tourist clichés and might not suggest the depth of emotion plumbed by 'thrilling' and 'dear,' they were nevertheless terms not readily applied to Australia. Britain's past allowed the indulgence of unfamiliar sentiments. Similarly it awakened such other atrophied sensations as 'reverence' and 'veneration.' Oxford (Abbott 1905: 83), St Paul's (Brown, L. 1910: 50), Dr Livingstone's cottage (Nixon 1928: 29 October) and the Temple (Napier 1933: 78) were discovered by the Australian tourist to be 'venerable'; 'veneration' was to be had in Westminster Abbey: 'Even if, in black mood or otherwise, he thinks or cares little for the England of to-day ... he cannot but stand 
here in awe and veneration' (Abbott 1905: 82-83). Westminster Abbey also inspired 'reverence' (Donnell 1915: 30 June; Abbott 1905: 72; Lahey 1941: 48), as did Windsor Castle (Napier 1933: 100), Bothwell Castle (Nixon 1927: 18 December), Middle Temple Hall (Napier 1933: 82) and Edinburgh Cathedral (Boucaut 1906: 101). Tintern Abbey was 'capable of forcing reverence into one's mind, whether one realises it or not' (Lahey 1941: 59). In Oxford Abbott noted how this newfound veneration contrasted with 'the characteristic irreverence which we have been assured Australians possess to a degree' (1905: 81).

What all these responses to British history have in common, I would argue, is that sense of ready personal connection, rousing the intimate emotions of an almost domestic relationship that enables the tourist to sit comfortably within a flow of history. For a century Australians of the class with access to overseas travel had shared a relaxed and comfortable middlebrow culture in which British history specifically provided many of the signposts. They knew its celebrities and sacred sites intimately. British history was not exotic, dashing, sublime, anarchic, irrational, romantic, dramatic, scandalous or sensual. Such terms would be fitting for the past they found in the rest of Europe, but not for the domestic atmosphere of Britain. In Britain it was picturesque rather than sublime, and all very chaste. On this point at least Australian tourists stood in stark contrast to one of their favourite travel writers, H. V. Morton, in whose In Search of England and other books between the wars travel became erotic adventure. Among his papers he kept a list of over 100 sexual conquests made while conducting his research (Bartholomew 2004: 24, 30; White, R. 2009: 11.4).

Gender, age and political persuasion did not seem to matter in this. Men and women, young and old, radical and conservative seemed to share the feeling for the thrilling, the quaint, the dear, the picturesque, the venerable. But this 'travelling class' was not representative of Australia (White, R. 1987a). They were an elite with the leisure and means to get to Europe before the advent of jumbo jets, though that elite could be surprisingly broad (Woollacott 2001: 17). They generally possessed the cultural capital of the middlebrow: they were the ones who had paid attention to history lessons at school. Their mind-set - the 'structure of feeling' to use Raymond Williams's term (1961) — carried weight and permeated Australian culture more thoroughly than other perspectives, and part of the reason for their cultural dominance was that as travellers 
they could claim all the spurious authority of the eye-witness (White, R. 2008). But it did not add up to 'the' Australian view of Britain.

In fact it was something more. It is a mistake to read their deeply felt responses to the British past as merely expressions of empire loyalty. Some-Liberal Prime Minister Robert Menzies the supreme example (Brett 1992: 145)—did recruit their emotional attachment for ideological purposes and certainly this sentimentality gave added potency to imperial allegiances. But we reduce too much to merely geopolitical identity, be it national or imperial. When these tourists engaged with the past they were not lying back and thinking of England: the emotional attachment to the past was not simply attachment to empire. We might say the intensity of emotion was the equivalent of that felt by later Australian tourists visiting Gallipoli: another past discovered on the other side of the world (Scates 2006; McKenna \& Ward 2007). In both cases the emotionalism points to something deeper than merely expressions of imperial or national loyalty. Their attachment to Britain's past represented a nostalgia for deeper meaning, a sense of escape from the everyday, a pleasure derived not just from ruins but also from entering the imagination and associating with popular culture's historic celebrities. They cherished their experience of escaping to the past precisely because, as in another country, 'they do things differently there.'

\section{Doing the continent}

Like so many Australian tourists throughout history, I have no time to 'do' the continent adequately here, but some of the contrasts between tourist responses to the past on either side of the Channel are instructive. First, the past did not loom as large on the continent. There were of course visits to old sites, to castles and cathedrals and palaces, but the architecture tended to receive more attention than the historical associations. Generally it was not felt to be a past of which they could claim ownership: it offered a sense of otherness rather than connection. For some that otherness was alienating; for others, as cosmopolitanism became a sign of cultural sophistication and a means of delineating social distinctions, the continental past was exciting. Whether alienating or exciting, history was to be watched as if in an audience, always with a distance from the stage. History there could be entertaining, curious, romantic, but it was not a history that connected the past to their particular present. History in Europe was much more about oddities and irrational hot-blooded temperament. Dr Hinder contemplated the difference 
when he visited the Tower of London in 1911: 'I noticed that my women folk seemed to dwell most on the horror side of the show. No doubt they would deny this. Blood and torture I have no time for ... Served up hot like in Madrid it was different but not this way' (1911-12). Violent hot-blooded history was what was expected on the continent, but not in Britain. Allison Howarth shared the distaste for the 'horror side' and made a similar distinction: 'This feeling is even worse on the Continent, where the palaces are magnificent beyond description' (Howorth 1937: 151). It looks like a non sequitur but it was of a piece: horrors and magnificence were continental, not British.

Frank Clune, that hugely popular and populist mid-century travel writer, stridently antiintellectual, anti-communist and pro-Australian, summed it up, admittedly not long after the end of World War II:

\footnotetext{
Europe is very interesting, but-

It has too many people, too many different kinds of people in it. Too much excitement, too many wars, have made the Europeans slightly crazy, maybe ... They are panicked with fears, hates and jealousies ... They kill one another in millions now, and smash one another's houses and temples to smithereens in spite and hate. (1950: 200-1)
}

Along with continental over-excitement went a sensuality. History across the Channel was far more sensual, if not downright erotic. It is difficult to eroticise the history of school books, but easier, perhaps, a history discovered as a 20 year old, through university or through a more sophisticated cultural diet: the seamy reputation of the French novel and theatre in the mid-nineteenth century applied just as much to French cinema a century later. So if Australian tourists retrieved their childhoods in Britain, they found their adolescence on the continent.

Consider the overwrought excitement of Nina Murdoch, a prolific Australian travel writer of the 1930s, describing the 'rapture and the wonder of the first exodus from a new world to the old ... Sometimes in Italy joy rose to such a pitch in me that it was only by the grace of God and early discipline that I did not career-a Maenad drunk with delight—screaming with ecstasy across the face of the Continent!' (1930: 1-2). Not a response commonly elicited by Britain's past, despite the emotion it could kindle. Waking on her first morning in Europe, in Nice, Murdoch flirted outrageously with old Europe: 
'Il fait beau ce matin pour ma'moiselle!' says the waiter as he puts my petit déjeuner beside the bed.

Sweet insinuation that the morning should make itself fine on my account! And 'ma'moiselle!' With the scratches of nine years' service on my wedding ring! ...

I have had my bath, and am clad in a single stocking when there rises from beneath the little white balcony of my room, the light music of a guitar.

Enchanting! ...

The guitar plays softly on; and now above it rises the warmth and passion of a baritone voice, in a rich little song of love, swelling with passion ... I am constrained to drop my other stocking and execute a Spanish pas seul —not as practiced or as graceful as his song, but, I assure you, no less filled with joy. (5-7)

That morning she sat in the hotel garden where

a Frenchman in a strawboater ... never takes his eyes from me in the hope that I may be feeling flirtatious on such a delicious morning ...

And now at luncheon the waiter-groomed like a Michael Arlen hero on the eve of romantic adventure - pours my humble glass of water as if it were an oblation. (9).

Needless to say Nina Murdoch preferred to travel without her husband (Edgar 1986).

Or consider Colin Simpson, the most popular Australian travel writer in the 1960s, for whom being sophisticated meant being frank about sex (White, R. 1997; 2012). He opened his best-selling 1959 book on Europe with a word picture. It was midnight and he was eating his first smoked eel on toast with a 'KLM air hostess' who had agreed to show him around Amsterdam. They listened to a 'gilded old clock-tower'; it had been chiming the hours when 'Sydney was still gum-trees and goannas.' Sitting there, 'The picture-book had come to life, and you were in it' and he could tick off the typical images: tulips, Volendam, original Rembrandts and 'those eye-popping living pictures, the girls who nightly sat framed in the front windows of the brothel houses down by the Zeedijk.' In a telling phrase, 'It was a little like being out of school at last, and a kind of coming of age' (Simpson 1959: 3-4). Similarly, in France, he played on the romance of Paris in the springtime. He looked out for young lovers (290) and regarded the man selling dirty postcards outside Cooks as 'a touch of true-to-label Paris' (286). He lingered in the Folies-Bergère, the Lido ('a big bevy of beautiful showgirls ... without a brassiere between them, or in need of one' 315), strip-tease shows (320) and red-light districts (321). With all that sophisticated romance, there was relatively little time for history. In contrast, arriving in London for the first time was 'a crossing from what was 
foreign to what is familiar; for, though the eye may be seeing it for the first time, the mind has known much of it for years' (365). There he would find much more history and much less sex.

\section{Coming home}

I suggested at the outset that tourists were important as agents of history. Their discovery of deep feelings for a deep past in Britain had ramifications for Australian culture. Some returned to seek out that same sense of connection to the past in Australia. A number of historians - Keith Hancock, Manning Clark, Noel McLachlan—have noted how being in Europe inspired them to look to Australia as a field for their history. But well before them, popular writers, mere tourists, had followed a similar path. Randolph Bedford began turning his own past into historical novels even while travelling. Then, 'just after my return,' when camped in central Australia, he conceived a project that would combine autobiography and Australian history: 'relating a boy's dreams, his mental processes and his development would be the story of the development of the boy's environment and therefore of the passing Australia and its scenes worthy of remembrance' (1976 [1944]: xi). J. H. M. Abbott returned to Australia to write newspaper articles on Australia's colonial past and a series of novels: Sally: The Tale of a Currency Lass (1918), Castle Vane: A Romance of Bushranging on the Upper Hunter in the Olden Days (1920) and Sydney Cove (1923). And Nathan Spielvogel, who had spent his life's savings 'to see the lands of the past' (1907: 4), returned to write popular histories of Eureka. As he slipped back into 'the once disliked, but now appreciated, routine,' he decided that 'all the wonders I have seen,' existing as they were alongside poverty and militarism, were no match for 'the blue sky above, the spreading gums around, ${ }^{10}$ the innocence and the simple faith of my little people ... My own land is the best land. Adieu' (124). Such sentiments were fairly common among Australians surveying the European past: admiration tempered by democracy.

But Spielvogel's travels were not over. After 'another attack of the Wanderlust,' he spent four years as a relief teacher exploring Victoria, the 'land of the Gumsucker,' before publishing A Gumsucker at Home in 1914 (9). The interplay between the global and the local paralleled that between past and present. In Castlemaine, he recalled being in Rome and visiting the Coliseum in the hope of communing with ancient history. 'But

\footnotetext{
${ }^{10} \mathrm{He}$ was an enthusiast for the gum tree, writing poetry to the mighty gum (Kaldor 2010: 61).
} 
I could summon up no spirits from the past' he said. Interrupted by an annoying American, ${ }^{11}$ 'the ghosts would not walk. All I caught was a cold, so with a sigh I wandered back to my hotel' (81). But in Castlemaine he discovered 'the men who did to Victoria what these Romans did for Rome ... the pioneers of one of the goldfields ... the failures, who missed their chances, and are now in the shadows ... pitching their tales of "them good old times." In Castlemaine he discovered 'a chapter of Victorian history' (81-82). So Spielvogel's travels in Europe kindled an appreciation of the past in Australia, one largely limited to gold rushes, pioneers and bushrangers but also redolent of what he called, in a wonderful phrase, its 'ruins, architectural and human' (1914: 85).

\section{Acknowledgements}

This article draws on research associated with two ARC Discovery grants, on Australian tourism in Britain and the development of 'historic' tourism in Australia, for which I would like to thank the ARC. It owes much to Alex Roberts, an excellent research assistant, and benefited from a Harold White Fellowship at the National Library of Australia in 2011 and a Senior Research Fellowship at Monash University in 2012. Finally I would like to thank Juliana de Nooy for the invitation to present a keynote paper at the 'Australians Abroad' conference in 2011 and the anonymous referees and others who provided comments on earlier drafts.

\section{Reference List}

Abbott, J. H. M. 1905, An Outlander in England: Being Some Impressions of An Australian Abroad. Methuen \& Co., London.

Alomes, S. 1999, When London Calls: The Expatriation of Australian Creative Artists to Britain. Cambridge University Press, Melbourne.

Atkinson, A. 2003, 'Heritage, Self, and Place,' Australian Cultural History, vol. 22: 161-71.

Barr, M. 2009, 'Sex, Art and Sophistication: The Meanings of "Continental” Cinema,' Journal of Australian Studies, vol. 33, no. 1, March: 1-18.

Bartholomew, M. 2004, In Search of H. V. Morton. Methuen, London.

Bedford, R. 1914, Explorations in Civilization. Syd. Day, Sydney. 1976 [1944], Naught to Thirty-Three, $2^{\text {nd }}$ edition. Melbourne University Press, Melbourne.

Blakie, F. J. 1903, Diary. Mitchell Library (ML) MSS 4376.

Blomfield, I. S. 1909, Memoirs, Blomfield papers, 1812, 1865-ca. 1940s. ML MSS 6958.

Boucaut, Sir J. P. 1906, Letters to My Boys: An Australian Judge and Ex-Premier on His Travels in Europe. Gay \& Bird, London.

Boxall, J. R. 1952-1953, Letters to Mrs J.P. Lane, Boxall Family Papers, 1952-1988. ML MSS 6343/1/2.

Brett, J. 1992, Robert Menzies' Forgotten People. Macmillan, Sydney.

Britain, I. 1997, Once an Australian: Journeys with Barry Humphries, Clive James, Germaine Greer and Robert Hughes. Oxford University Press, Melbourne.

Brown, A. D. 1916-17, Diary, 7 January 1916-3 November 1917. ML MSS 17.

Brown, L. 1910, Letters from an Australian Abroad. The Cumberland Argus Printing Works, Parramatta. Buzard, J. 1993, The Beaten Track: European Tourism, Literature and the Ways to Culture, 1800-1918. Oxford University Press, Oxford.

\footnotetext{
${ }^{11}$ The figure of the crass American Abroad was an even more potent emblem of nationality than the Australian, not least for Australians for whom it provided some solace in their anxieties about their own philistinism. Interestingly the Australian Abroad could play the same role for Americans - in, for example, F. Scott Fitzgerald's Tender is the Night (2009: 272-75).
} 
Campbell, S. 1932-1933, Diary of his Voyage to England and His Time There (2 volumes), with Two Loose Tables of Expenses, Diaries and Related Papers, 1928-1949. ML MSS 7215; CY 4317.

Clune, F. 1949, Land of Hope and Glory. Angus \& Robertson, Sydney. 1950, All Roads Lead to Rome: A Pilgrimage to the Eternal City, and a Look Around War-torn Europe. Invincible Press, Sydney.

Cohen, A. J. 1938, Diary, Cohen Papers, 1899-1973. ML MSS 6032.

Corsellis, E. 1953, Letters to Her Father, Family and Friends, Corsellis Papers, 1887-1989. ML MSS $6555 / 2$.

1954, Letters to Her Grandmother Mainly from England and Europe, Corsellis Papers, 1887-1989. ML MSS 6555/2. 1953-1954, Diaries, Corsellis Papers, 1887-1989. ML MSS 6555/1. 1975, Diary (Transcript), Corsellis papers, 1887-1989. ML MSS 6555/1.

Curran, J. 2004, The Power of Speech: Australian Prime Ministers Defining the National Image. Melbourne University Press, Melbourne.

Donnell, Sister A. 1915-1918, Circular Letters, 25 May 1915-1918 July 1918. ML MSS 1022/1; CY 2459.

Dowding, M. 1928, Diary, Dowding Papers, 1928-1956. ML MSS 4249/1; CY3444. 1956, Diary, Dowding Papers, 1928-1956. ML MSS 4249/2.

Edgar, S. 1986, 'Murdoch, Madoline (Nina) (1890-1976),' Australian Dictionary of Biography, National Centre of Biography, Australian National University. Online, available: http://adb.anu.edu.au/biography/murdoch-madoline-nina-7694/text13469 [Accessed 1 December 2011].

Falkiner, U. C. 1938, Diary. ML MSS 423/44-48.

Fitzgerald, F. S. 2009 [1934], Tender is the Night. Penguin, London.

Freud, S. 1936, 'A Disturbance of Memory on the Acropolis: An Open Letter to Romain Rolland on the Occasion of His Seventieth Birthday,' The Standard Edition of the Complete Psychological Works of Sigmund Freud. Hogarth Press, London, vol. 22: 239-48.

Garnsey, A. H. 1930, Diary, Garnsey Papers, 1885-1944. ML MSS 7101/1.

Girl Guides 1937, Diary, 1937-1938. ML MSS 2494.

Glading, S. 1946-1948, Letters to Gladys Roberts, Roberts Correspondence. ML MSS 5116 ADD-ON 2113.

Gore, S. 1958, Australians, Go Home! Robert Hale, London.

Hassam, A. 2000, Through Australian Eyes: Colonial Perceptions of Imperial Britain. Melbourne University Press, Melbourne.

Hinder, Dr H. V. C. 1911-1912, Diary, Frank Hinder Further Papers, 1895-1992. ML MSS 5720 ADDON 2026/4.

Holland, P. \& Huggan, G. 1998, Tourists with Typewriters: Critical Reflections on Contemporary Travel Writing. University of Michigan Press, Ann Arbor.

Howorth, A. 1937, 'Cooee’ England: A Travel Diary. George Batchelor, Melbourne.

James, F. 1927-1933, Correspondence with Her Family, 1916-1990, Florence James Papers, 1890-1993. ML MSS 5877/9.

James, Mr \& Mrs A. H. C. 1930, Letters, Tremlett Family Papers, 1872-1973, Together with Papers of the James Family, ca. 1905-1942. ML K 04231.

Kaldor, L. 2010, 'Gum Tree,' in Symbols of Australia, (eds) M. Harper \& R. White. UNSW Press \& National Library of Australia, Sydney \& Canberra.

Kendall, L. 1951, Visit to Britain. Peterson Brokensha, Perth.

Lahey, E. M. 1941, We Decided to Go-Notes of A Journey. W. R. Smith \& Patterson, Brisbane.

Lawrence, R. L. L. 1930, Diary, in folder '1913-1956 Miscellaneous Souvenirs ...' Lawrence Catley, Catley and Lawrence Families Papers, 1868-1979. ML MSS 5850/1.

Lloyd, M. 1901, Wanderings in the Old World and the New. Vardon and Pritchard, Adelaide.

Lowenthal, David 1985, The Past is a Foreign Country. Cambridge University Press, Cambridge.

Macaulay, R. 1953, The Pleasure of Ruins. Thames \& Hudson, London.

Macaulay, T. B. 1840, Review of Leopold von Ranke's The Ecclesiastical and Political History of the Popes During the Sixteenth and Seventeenth Centuries, Edinburgh Review, no. 72, October: 22758.

Maddern, I. T. 1960, Dear Everybody. Hedges \& Bell Ltd, Victoria.

McDonald, W. R. 1944, By Bomber to Britain. Telegraph Newspaper Company, Brisbane, 1944.

McKenna, M. \& Ward, S. 2007, "It was Really Moving, Mate": The Gallipoli Pilgrimage and Sentimental Nationalism in Australia,' Australian Historical Studies, vol. 38, no. 129: 141-51. 
Meaney, N. 2001, 'Britishness and Australian Identity: The Problem of Nationalism in Australian History and Historiography,' Australian Historical Studies, vol. 32, no. 116: 76-90.

Millear, M. M. 1902, The Journal of a Wandering Australian. Melville \& Mullen, Melbourne.

Morton, H. V. 1927, In Search of England. Methuen, London.

Moss, J. 1922, My Diary of a Short Trip to England. Ruskin Press, Melbourne.

Murdoch, N. 1930, Seventh Heaven: A Joyous Discovery of Europe. Angus \& Robertson, Sydney.

Napier, S. E. 1933, Walks Abroad: Two Australians in the Wilds of England, Scotland, and Ireland, $3^{\mathrm{rd}}$ edition. Angus \& Robertson, Sydney.

Nietzsche, F. 1980 [1874], On the Advantage and Disadvantage of History for Life, (trans.) P. Preuss. Hackett, Indianapolis.

Nixon, J. 1927-1929, Letters, Nixon Family Papers, 1889-1942. ML MSS 7813

Nora, P. 1989, 'Between Memory and History: Les Lieux de Mémoire,'Representations, no. 26: 7-25.

Ousby, I. 1990, The Englishman's England: Taste, Travel and the Rise of Tourism. Cambridge University Press, Cambridge.

Pattinson, F. 2007, Send More Money Please Daddy: Letters from Abroad 1954-55. Holmesglen Institute of TAFE, Melbourne.

Pesman, R., Walker, D. \& White, R. (eds) 1996a, The Oxford Book of Australian Travel Writing. Oxford University Press, Melbourne. 1996b, An Annotated Bibliography of Australian Overseas Travel Writing, compiled by T. McCormack. ALIA Bibliographies on Disk, Canberra.

Reid, E. 1900, Diary. ML MSS 6565.

Richardson, Mrs M. 1904 Manuscript Diaries Covering Her Years of Study Abroad 1899, 1904-1906. ML B1687; CY973.

Roberts, A. 2008, 'Lessons in Social Progress: What Australian Tourists Learnt in Britain,' British Australian Studies Association Biennial Conference, University of London, unpublished paper.

Roberts, H. G. 1937, Journal of a Trip from Sydney to Europe. ML MSS 2602.

Samuel, R. 1994, Theatres of Memory. Verso, London.

Sanders, W. 1928-1929, My Trip Abroad. ML MSS 7446.

Scates, B. 2006, Return to Gallipoli: Walking the Battlefields of the Great War. Cambridge University Press, Melbourne.

Simpson, C. 1959 [1965], Wake Up in Europe: A Book of Travel. Angus \& Robertson, Sydney.

Sinclair, Hon J. R. 1913, The Homeland Revisited: The Hon. J. R. Sinclair's Impressions. Daily Times Print, Dunedin.

Sisson, J. 1953, A Tour by Car through England, Scotland and Wales. Bank of NSW, Sydney.

Skilton, D. 2004, 'Contemplating the Ruins of London: Macaulay's New Zealander and Others,' London Journal, March. Online, available: http://homepages.gold.ac.uk/londonjournal/march2004/skilton.html [Accessed 4 November 2011].

Sobocinska, A. 2010a, Personal Engagements: Australian Travel to Asia 1941-2009, PhD thesis, Department of History, University of Sydney. 2010b, 'The Language of Scars: Australian Prisoners of War and the Colonial Order,' History Australia, vol. 7, no. 3: 59.1-59.20. 2011, 'Innocence Lost and Paradise Regained: Bali and Australia's Place in the World,' History Australia, vol. 8, no. 2: 199-222.

Sommerlad, E. C. 1939, Circular letters, Sommerlad Family Papers, 1857-1992. ML MSS 6012/3-4.

Soul, G. 1899, Journals of Gertrude A. Soul. Soul Family Papers, 1856-1972. ML MSS 6197.

Soul, W. H. 1899, Journal of a Trip to Europe and America Leaving Sydney $29^{\text {th }}$ March, 1899-And Returning to the Same Place January, 1900, Soul Family Papers, 1856-1972. ML MSS 6197.

Spielvogel, N. 1907, A Gumsucker on the Tramp, $4^{\text {th }}$ edition. G. Robertson, Melbourne. 1914, The Gumsucker at Home. G. Robertson, Melbourne.

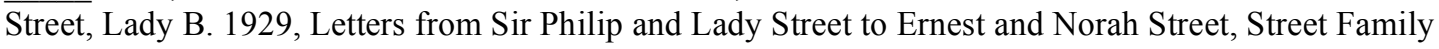
Papers. ML MSS 1933.

Street, Sir P. 1929, Letters from Sir Philip and Lady Street to Ernest and Norah Street, Street Family Papers. ML MSS 1933.

Symons, M. 1982, One Continuous Picnic: A History of Eating in Australia. Duck Press, Adelaide.

Taylor, G. A. 1918, 'Those Were the Days': Being Reminiscences of Australian Artists and Writers. Tyrrell's, Sydney.

Trinca, M. 2009, 'Part of the Pageant: Australian Tourists in London,' in Australians in Britain: The Twentieth Century Experience, (eds) C. Bridge, R. Crawford \& D. Dunstan. Monash e-press, Melbourne. Online, available: 
http://books.publishing.monash.edu/apps/bookworm/view/Australians+in+Britain\%3A+The+Twe ntieth-Century+Experience/137/xhtml/chapter12.html [Accessed 4 November 2011].

Trinca, M. 2010, Part of the Pageant: Australian Tourists in London after World War 2, PhD thesis, Department of History, University of Sydney.

Twigg, A. B. 1968, Diary 21 June-24 July 1968-Holiday to the USA, Ireland, England, Italy and Hong Kong. ML MSS 4015.

Walton, J. 2009, 'Marketing the Imagined Past: Captain Cook and Cultural Tourism in North Yorkshire,' in Managing Regional Tourism: A Case Study of Yorkshire, England, (ed.) T. Rhodri. Great Northern Books, Ilkley: 220-32.

Ward, S. 2001, Australia and the British Embrace The Demise of the Imperial Ideal. Melbourne University Press, Melbourne.

Watson, N. 2006, The Literary Tourist: Readers and Places in Romantic and Victorian Britain. Palgrave, Basingstoke.

White, H. 1973, Metahistory: The Historical Imagination in Nineteenth-Century Europe. Johns Hopkins University Press, Baltimore.

White, R. 1981, Inventing Australia: Images and Identity, 1688-1980. Allen \& Unwin, Sydney. 1986, 'Bluebells and Fogtown: Australians' First Impressions of England 1860-1940,' Australian Cultural History, vol. 5: 44-59.

1987a, 'Overseas,' in Australians: A Historical Library, Vol. 4: Australians 1938, (eds) B. Gammage \& P. Spearritt. Fairfax Syme Weldon, Sydney: 435-45.

1987b, 'The Soldier as Tourist: The Australian Experience of the Great War,' War \& Society, vol. 5, no. 1: 63-77.

1997, 'The Retreat from Adventure: Popular Travel Writing in the 1950s,' Australian Historical Studies, vol. 28, no. 109: 90-105.

2001, 'Cooees across the Strand: Australian Travellers in London and the Performance of National Identity,' Australian Historical Studies, vol. 32, no. 116: 109-27.

2008, 'Australian Journalists, Travel Writing and China: James Hingston, the "Vagabond" and G.

E. Morrison,' Journal of Australian Studies, vol. 32, no. 2: 237-50. 2009, 'Australian Tourists in Britain 1900-2000,' in Australians in Britain: The Twentieth Century Experience, (eds) C. Bridge, R. Crawford \& D. Dunstan. Monash e-press, Melbourne. Online, available:

http://books.publishing.monash.edu/apps/bookworm/view/Australians+in+Britain \%3A+The+Twe ntieth-Century+Experience/137/xhtml/chapter11.html [Accessed 4 November 2011]. 2012, 'Armchair Tourism: The Popularity of Australian Travel Writing,' in Sold to the Millions: Australia's Bestsellers, (eds) A. Sarwal \& T. Johnston-Woods. Cambridge Scholars Publishing, Newcastle upon Tyne: 182-202.

2013 (forthcoming), 'British Travellers and Australia's Past,' in The British Abroad, (eds) M. Farr \& X. Guegan. Manchester University Press, Manchester.

White, R. \& Oldmeadow, L. 2009, 'Australian Tourists and English Food,' in Beyond the Supermarket: Learning to Overcome Gastronomic Poverty, (eds) P. Mead \& S. Bryan, Proceedings of the $15^{\text {th }}$ Symposium of Australian Gastronomy 2007, Hobart: 28-35.

Williams, R. 1961, The Long Revolution. Chatto \& Windus, London.

Woollacott, A. 2001, To Try Her Fortune in London: Australian Women, Colonialism and Modernity. Oxford University Press, Oxford.

Young, D. 1996, Making Crime Pay: The Evolution of Convict Tourism in Tasmania. Tasmanian Historical Research Association, Hobart. 